\title{
VIOLENCE WITHOUT A FACE: THE ANALYSIS OF TESTIMONIES OF WOMEN WHO WERE SEXUALLY ASSAULTED DURING THE WAR IN CROATIA AND BOSNIA AND HERZEGOVINA
}

\author{
Slavica Kozina ${ }^{1}$, Mirela Vlastelica ${ }^{1,2}$, Josip Anđelo Borovac ${ }^{1}$, Tonći Mastelić ${ }^{1}$, \\ Domagoj Marković ${ }^{3} \&$ Mladen Lončar ${ }^{4,5}$ \\ ${ }^{I}$ Department of Psychological Medicine, University Hospital Center Split, School of Medicine, \\ University of Split, Split, Croatia \\ ${ }^{2}$ Private Psychiatric Office, Split, Croatia \\ ${ }^{3}$ Department of Internal Medicine, University Hospital Center Split, Split, Croatia \\ ${ }^{4}$ National Center for Psychotrauma, Department of Psychiatry, University Hospital Center Zagreb, Zagreb, Croatia \\ ${ }^{5}$ School of Medicine, University of Zagreb, Zagreb, Croatia
}

received: 16.8.2017;

revised: 18.10.2018;

accepted: 22.11 .2018

\section{SUMMARY}

Background: This study examined testimonies of women who were sexually assaulted multiple times by multiple unknown offenders. In these testimonial narratives, it is possible to detect specific modalities of traumatic event expression. This expression lacks any spatial, temporal, auditory or emotional determinants of the event.

Subjects and methods: These fourteen women (out of 17) were imprisoned and forcefully isolated in detention camps or private houses in the occupied territories of Croatia and Bosnia and Herzegovina, during the war. At the same time, some of these women were raped by the offenders that were previously known to them. The average length of detention was 141 days among the seventeen victims (range of 7 to 395 days), while the average time from the first day of imprisonment to the first day of testimony was 311 days (range of 30 to 889 days).

Results: Based on the narrative descriptions of the events acquired from these testimonies, our analysis showed that these expressions differed when the offender was known to the victim, contrasted to the situation when the offender was completely unknown. This finding has a significant implication in victim's testimony at judicial hearings. Specifically, women that were raped by unknown perpetrator(s) were often unable to provide persuasive testimony and their recollection of the events was deemed insufficient for the further prosecution. Testimonies in these cases substantially lacked in vividness and were devoid of visuospatial determinants of the rape event. Consequently, this often resulted in the case's dismissal.

Conclusion: The unusual and problematic expression of these traumatic memories might indicate that these events were not properly stored in the conceptual form of memory. Ultimately, victims could not make any coherent recollection or reconstruct the cascade of events by using perceptual information. We argue that this could be due to an aberrant mechanism of memory storage and difficulties that emerge on the level of sensory input. This problem needs to be further examined and correspondingly accounted for since it can exert significant influence on judicial outcomes in the domain of sexual assault cases worldwide.

Key words: sexual violence - rape - trauma - psychotrauma - war

$$
* * * * *
$$

\section{INTRODUCTION}

During the war in Croatia (1991-1995) the acts of sexual abuse and rape were officially documented among 182 women. Rape was confirmed in 57 cases and 36 of those cases were judicially processed. Out of 36 cases, only 15 known perpetrators were convicted due to rape charges (Public Prosecutors Office Republic of Croatia 2014). This shows that the rate of conviction is unusually low, especially taking into account that some cases involved multiple rapists (up to 5 perpetrators).

The conviction rate of sexual offenders in Bosnia and Herzegovina has been low over the years, in some aspects even more dramatic than in Croatia. The Office of the United Nations High Commissioner for Refugees (UNHCR) estimated that more than 20000 raping events occurred in Bosnia and Herzegovina, dominantly against Muslim women (UNHCR 2003). Rape activities during the war in Bosnia were committed in the following manner: a) rape activities organized through official authorities that overtook control of occupied territories, b) rape events that occurred in general detention centers, c) rape events that occurred in detention centers built for the sole purpose of rape (Aydelott 1993). In terms of sexual violence in Bosnia, official reports state that 76 processes were judicially prosecuted and out of those, 66 were finalized in the courts in Bosnia. At the end of 2013, 35 cases still remained opened (OSCE 2014). Mlinarević et al. (2012) reported that only about 30 cases that involved sexual assault and abuse were processed in Bosnia as of 2012. These cases involved the testimonies of 150 women that were victims of sexual assault. This constitutes only a minuscule proportion of the overall cases, which certainly makes this phenomenon something that should be seriously studied. Many of the surviving victims of sexual abuse 
and war rape, both in Croatia and Bosnia, clearly have a difficult time proving that they were indeed and undoubtedly the victims of sexual assault.

In addition to substantial physical, emotional and social damage that are endured by these victims, they also need to face with their common non-specific and often incomplete memories or recollections. This fact significantly complicates their case as the supporting evidence (key witnesses, physical forensic evidence) is frequently absent or inadequate to a sufficient degree. A document published by the International Criminal Tribunal for the former Yugoslavia (ICTY) in 2015 tried to set guidelines for the future prosecutions of sexual crimes committed on an international scale, did not, in our opinion, address the necessary specificities of individual testimonies provided by victims who were raped by multiple unknown perpetrators (Office of the Prosecutor International Criminal Tribunal for the former Yugoslavia 2015).

Some authors claim that the traumatic memory is adaptive and prone to a subjective distortions. This is based on the experimental research that investigated inaccuracies in recalling neutral information, a disinformation effect, and other errors of memorization that included temporal determinants and memorization errors during childhood (Hyman \& Loftus 1998). The recall of the traumatic event is complicated by the neutral information and daily events that interfere with the traumatic event. The distortion of the memory can be conditioned by incorrect information that was processed post-event, a single scene from a traumatic event can be distorted and inserted in autobiographic memory. Studies of real traumatic events also suggest that the memorization of such events is variable and subjected to personal distortions (Fergusson at al. 2000).

According to Tulving (1983, 1985), episodic memory contains a subjective representation of the subjective time, including self-consciousness and self-experience. Negative emotional content can strongly disrupts the coherences of episodic memory (Bisby at al. 2018). Every episodic memory contains a mental represen of selfness, either through activity, stimulus and/or experience. A certain moment, regardless of unexpected brain damage or a stressful traumatic event can alter the way of processing information in respect to the past or future (or both) as exemplified in cases of anterograde or retrograde amnesia (Tulving 1989). The roles of episodic memory are: 1) to construct self-awareness (self) and 2) to process events or personal episodes (Tulving 1989, 1992, 1993, 2002, Tulving \& Markowitsch 1998). The brain can alter neural maps by consistently processing the information in a way that the patient is not able to recognize information on a long term basis or cannot recall old, already stored information. As a consequence, the fallout of autobiographic episodes occurs during the processing of the emotionally highly colored events. Baddeley introduces a somewhat different viewpoint that resembles Tulving's concept of episodic memory (Tulving 2002). His concept assumes that the episodic memory is a temporary store that can be preserved in densely amnesic patients with grossly impaired episodic long term memory (LTM). It plays an important role in feeding information into and retrieving information from episodic LTM. Baddeley (Baddeley 2002) proposes an episodic buffer that serves as an interface between ranges of systems, each involving a different set of codes. It is assumed that it achieves this by using a common multi-dimensional code. The buffer is assumed to be limited in capacity because of the computational demand of providing simultaneous access to the necessarily wide range of different codes (Baddeley 2002). The episodic buffer can be accessed by the central executive through the medium of conscious awareness. The executive, can, furthermore, influence the content of the storage by attending to a given source of information, whether perceptual, from other components of working memory, or from LTM. As such, the buffer provides not only a mechanism for modeling the environment, but also for creating new cognitive representations, which in turn might facilitate problem solving. Results of these investigations have implications in clinical practice recalling is a reconstructive process and is prone to errors. We cannot claim with high certainty that the memories are fully correct and true to actual events. The report about an act of violence can be very consistent, but it does not have to be true. It would be recommendded to take the consistency of statement as a main indicator of accuracy and make conclusions based on the individual testimonies (Porter 2003, Morgan 2004). An extensive amount of cognitive research supports finding that anxiety hinders recall performance by disrupting the efficacy of working memory (Baddeley 1972, Moran 2016). Rapport's effect on witness memory may therefore be related to its effectiveness in reducing witness anxiety: a reduction in the state anxiety at retrieval via rapport building may allow the witness to allocate additional cognitive resources to recalling the criminal event (Vallano \& Schreiber Compo 2011, Kieckhaefer at al. 2014)

The main scope of this study was to analyze the restored memories about multiple rapes, forceful detention, captivity and isolation in respect to spatial, temporal, visual and auditory components of the event. We also provided special attention to emotional/ selfreflective responses of victims in pertaining to their traumatic experience. These memory recollections have been obtained from the testimonies of seventeen women who were sexually assaulted multiple times during the war in Croatia and Bosnia and Herzegovina.

\section{SUBJECTS AND METHODS}

\section{Background}

The "Multidisciplinary Assistance to Women War Victims Testifying for International Criminal Tribunal" 
program, established at the University of Zagreb School of Medicine through the Medical Centre for Human Rights, provided professional psychological and medical psychiatric help to 68 women raped during the war (in 1991-1995 period). The goal of this program was to provide permanent multidisciplinary assistance to female victims of war who decided to testify in front of the International Criminal Tribunal for the former Yugoslavia (ICTY) in the Hague, Netherlands. This project was envisioned as a leverage that could reaffirm the faith in women's fundamental human rights and could help to maintain their dignity and self-worth. In this regard, this project aimed to achieve international cooperation in segments of promotion, protection and encouragement of fundamental women's rights, especially of those women that were victims of war. (Several international instruments specifically address sexual and gender-based violence against women and girls. The Convention on the Elimination of All Forms of Discrimination against Women adopted by the General Assembly in 1981, the United Nations Declaration on the Elimination of Violence against Women, adopted by the General Assembly in 1993, and the Beijing Declaration and Platform for Action,adopted in Beijing in 1995, include all forms of discrimination as violence against women and girls and reaffirm States' responsibility to work to eliminate them.) This project was substantially supported by the relevant worldwide organizations such as: World Health Organization (WHO), European Commission, Norwegian People Aid and Internationale Gesellshaft für Menschenrechte (IGFM).

\section{Subjects and psychiatric evaluation}

Out of these 68 women included in the program, 21 were sexually assaulted on a daily basis during their captivity (Lončar at al. 2006). In this study we included testimony transcripts of 17 women out of these 21 . The remaining testimonies ( 4 of them) were not included in the study due to difficulties where victims could not explicitly say that they were sexually assaulted or they had extreme psychological difficulties. In addition, most details about their rapes were collected from eye witnesses and not from the victims themselves. It is important to highlight that all the transcripts included in this study were not modified through any possible intervention by a therapist nor were the victims interrupted during any phase of their free flowing narrative expression. All of these 17 women were victims of multiple rapes and they were the objects of sexual violation by at least two or more known and unknown men (soldiers in this case). They were kept as sexual slaves. Most recently, the 1998 July 17 Rome Statute of the International Criminal Court defines rape, sexual slavery, enforce prostitution, forced pregnancy, enforced sterilisation or any other form of sexual violence of comparable gravity as a crime against humanity United Nations Security Council Resolution 1325 (2000) emphasises
States' responsibility to end impunity for crimes against humanity and war crimes, including sexual and other forms of violence against women and girls. All observed victims were held in captivity for an average of 311 days.

The professional psychiatric assessment of all the rape victims $(\mathrm{N}=68)$ was performed in 2006 (Lončar at al. 2006). The assessment of psychological status of the victims took place in between 11.9 months and 2.4 years after the rape events. During this examination, 17 victims, who are the subjects in this study were evaluated as well, and they provided their testimony in an average of 151 days after the sexual assault (range 28-1065 days). These victims were on average 20.5 years of age (16 victims were in between 17-35 years of age while 1 victim was 68 years old); 8 were married, 9 were single while 9 of them had two or more children at the time when the sexual assaults occurred.

\section{Circumstances of sexual assault}

- The average length of captivity was 311 days (range 7-395): 8 women spent 7-30 days in captivity, 2 were held up to 2 months, two up to 5 months, while 5 of them were kept for at least half a year or more.

- All of the victims were sexually assaulted multiple times: 15 women were sexually assaulted by 3 or more perpetrators; one was raped by two and one by a single perpetrator.

- Fourteen victims were raped at least once at one of the state's institutions (courthouse, police station, municipality office etc.) when they looked for help; four were raped at least once at their home; three were raped in a refugee camp at least once, while 8 women identified a so-called "raping camp" as a place where they were sexually assaulted.

- 14 women shared physical space with other women who were raped on a daily basis; three victims were physically isolated from others and were held alone.

- Seven victims knew their rapists from before (2 were raped exclusively by known rapists while 5 victims knew some or most of their rapists from before).

- Ten victims had never seen or knew their rapists from before.

- Five assaults resulted in pregnancy and two victims decided to have an abortion.

\section{Methods of assessment}

The experience of sexual assault and multiple sexual abuse is a matter of a peculiar nature that cannot be manipulated for experimental purposes. Therefore, the qualitative investigational approach was the most appropriate method of choice for the exploration of this sensitive content of traumatic memories that involve rape, physical and sexual abuse and forceful captivity in 
war. Through the employment of a qualitative methodology (testimonial content analysis) in the exploration of traumatic memory, we tried to preserve the originality, individuality and idiographic quality of the each particular traumatic event.

Narrative studies are able to direct attention to common, fundamental and constitutive (ontological) determinants of human behavior. They provide a historical and empirical basis of exploring certain phenomena in respect to their temporal, relational, culturally specific or institutional elements (Somers 1994). The method of testimony used in this research was applied in Chile in 1971 for the first time, as a psychotherapeutic technique with the goal of reaching symptomatic relief (catharsis) among the victims of violence who survived the loss and disappearance of their relatives (Cienfuegos \& Monelli 1983, Kijak \& Pelento 1986). This procedure is based on the verbal expression of the traumatic event without any intervention of the therapist. The testimony is conducted in such a way that it enables relief for the victim, as well as the integration of the traumatic event. The psychotherapist records the testimony on an audio tape recorder and then the content is transcribed in written form along with the patient (Cienfuegos \& Monelli 1983). This process is founded on an essential patient-therapist relationship and trust.

Before the actual testimony begins, necessary preparations are conducted as well. These involve recording the details about the traumatic event, such as the names, dates, addresses and similar pieces of information. The addition to testimony can be any helpful scheme of the location or the situation associated with the traumatic event (Agger \& Jensen 1990). Any testimony that is structured and organized in this way can capture both the subjective component of the victim's testimony (personal \& spiritual dimension) and the objective component that has a value as a legal, public and political entity.

\section{Testimonial content analysis}

In our analysis, the method of "description of observed phenomena" has been utilized, without any intent to envisage the cause and consequences of the observed state. This method is commonplace in introspective psychology. It is analogous to description of the conscious contents without the preceding attribution of these contents (Chaplin 1985). By applying this method, the subjective experience of "self", during and after the rape event, has not been intentionally questioned during the testimony, unless the victim decided to speak freely about it. This method, however, has certain limitations. One that first comes to mind is the ability to generalize results and their interpretation in terms of identifying the cause and consequence. The beneficial aspect of this method is that it enables us to determine motives that need to be taken into account when describing certain behavior, in terms of its prediction and control (Weber
1990). While using this methodology, it is important to bear in mind that any personal story-telling consists of evaluative and emotional components that connect our previous life experiences with the development of our emotional self-awareness. Open-ended questioning consistently yields more accurate but less complete reports than the more directed forms (Lamb 2003). Particularly harmful to the accuracy of memory are leading questions, which, either by form or by content, suggest the desired answer to the witness (Bruck \& Ceci 1999). Thus, the general recommendation is that witnesses should first be allowed to tell their story in their own words before being subjected to more direct questioning, and that even then, greater faith should be placed in the accuracy of the former type of testimony (Geiselman \& Fisher 2014).

\section{RESULTS}

Every obtained testimony contains information about the circumstances of rape, the perpetrators who committed these acts, as well as the description where and when these crimes occurred (if such information is available). Testimonies are presented and divided in following categories:

- Cases in which the perpetrators were known to victim from before; 3 out of 17 victims;

- Cases in which some perpetrators were unknown to victims from before; 14 out of 17 .

The performed content analysis of the testimonies received from 17 raped women revealed some common ground:

- The mental imagery (Baddeley \& Andrade 2000) about the traumatic event in the memories of the victims.

- The perceptive determinants of the event that are embodied (This is in line with the findings of Pylsyshyn (1999) which showed that spatial and temporal properties are inherited from the observed scene, without need to posit a spatial properties of images).

- Narrative self-experience and the awareness about other people who were involved in the traumatic event.

\section{DISCUSSION}

\section{General remarks}

In this discussion we compared and analyzed differrences in narrative expressions gained through testimonies of victims who were raped by known and unknown perpetrators. These testimonies differ greatly in sense that they provide different breadth and quality of sensory information (auditory, visual, spatial, etc.). Women raped by unknown perpetrators generally exhibit simple, generalized and non-specific recollections about 
the traumatic rape event. Their storytelling is devoid of any palpable and specific anchor that could help in the prosecution of perpetrators during trial. In contrast to this, women who were raped by known perpetrator/s offer a coherent and clear structure of the chain of the events, their recollections are specific, vivid and rich. Recollection of the original event has been ongoing all the time. In the modern view of human memory memories are mental constructions. It is important to note that they are not reconstructions. They are not like videos, photographs or other recording media, even though they frequently contain mental imagery. They are transient constructions and although they may to some degree accurately represent the past they are timecompressed and contain many details that are inferred, consciously and unconsciously, at the time of their construction (Conway \& Loveday 2015).

Consequently, such testimonies of victims who were raped by known provide significantly more material that can help in the prosecution of the perpetrator, ultimately resulting in successful judicial outcomes. In the subsequent sections of the text, we offer an analysis of the mental imagery and self-reflective characteristics in the obtained testimonies.

For the didactic purposes, we divided these analyses in two categories - events in which the perpetrators were known to the victims and those in which perpetrators were unknown to the victims.

\section{Mental imagery in situations where the perpetrators were known to the victims (3 victims)}

Fragment from testimony of Croatian women, 18 years old, mother of a $1 \frac{1}{2}$ year-old child. Length of captivity: 19.11.1991 until 20.04.1992:

"I had sex with both of them at the same time. I remember I bled heavily during all of that. One of them (victim identified him) ordered another guy (identified him as well) to take a beer bottle and put it in my vagina. I think all of that lasted for about 2 hours. Then they let me put my clothes back on and took me home (victim was aware of her spatial location and named the address of the building) that was within 15 minutes of walking distance. One of them was holding me tightly by my arm (identified him). My younger sister (9 years old at the time) was walking along with me".

Fragment from testimony of a Croatian woman from Bosnia and Herzegovina, 22 years old, in $23^{\text {rd }}$ week of pregnancy. Got pregnant during captivity. Held isolated in a "private house". Length of captivity: 07.10.1992 until 28.06.1993:

"In the common area of the house, he threw me to the couch, ripped my clothes off and then he raped me (victim quoted his statements during this act). I tried to defend myself... and I screamed but that couldn't do much against him.
I think all of this lasted for about an hour. When I was left alone I only had my parents on my mind. I wondered what happened to them. I thought of jumping through the window but I still had some glimpse of hope that they might exchange me. Later that day S. came back and he brought some canned food to eat".

\section{Analysis}

In the testimonies of these three victims we have all the elements that constitute traumatic memory: episodic nature, imagery, vividness, a proper temporal and visuospatial orientation. Amnesia and recovered memory occur more often in response to victimization by known perpetrators, which is congruent with Frey's theory of betrayal trauma (Freyd 1996, van der Kolk 2001). Due to the dependent nature of the relationship between perpetrator and victim, the victim of the violation is unable to confront the perpetrator (Freyd 1996). The main feature of narration is the narrator's perspective, usage of direct speech and narration that follows the principle of interchangeable roles - "he said something to me, then I replied back". When describing the traumatic event, visuospatial determinants are clearly present. The victims almost sounds like documentary narrators - they describe each particular day, they mention their rapists and other people that were involved in the scenes. These people are often named or at least they are described in detail. The victims bring these characters into relationships. The whole testimony is told "in one breath".

Clear elements of dissociation are present, in terms of the "frozen affect" victims often retell their stories or events without affective reflection, but not in the way that it could be seen as a cognitive or emotionalpsychotic drift (observation made by the interviewer). In the testimony of the $2^{\text {nd }}$ victim some discrete elements of pity, worrying and self-questioning could be seen. All of this might indicate that the victim could have shown emotional investment in the relationship towards her captor - as seen in "Stockholm syndrome" (Freyd at al. 2005). In recognition memory, subjects experience at least two quite distinct states of awareness. Recognition is accompanied by either conscious recollection or feelings of familiarity in absence of any recollective experience. These two states of awareness can be measured by remembering and knowing responses (Tulving 1985). Remembering and previously knowing the perpetrators enables rape victims to recall memories and elements of the rape event, characterized by rich semantic and episodic memory, in Tulving's sense. From the standpoint of Tulving theory, the dissociations between remembering and knowing observed in recognition memory imply that both episodic and semantic memory systems contribute to the overall recognition performance. Similarly to Mandler's (1980) theory, our observations lie within the framework that assumes 
that the conscious recollection of traumatic events (that are committed by known perpetrators) depend on an elaboration process. Such integration subsequently gives rise to the victim's increased feelings of familiarity with the perpetrator. This is why their testimonial narratives are substantial, vivid and productive in terms of information availability.

\section{Mental imagery in situations where perpetrators were unknown to victims (14 victims)}

Fragments from testimony of Muslim woman, 17 years old, single. Imprisoned in camp and then transferred to a private apartment where she was sexually abused by multiple men. Length of captivity: May 1992 until $15^{\text {th }}$ of June, 1992:

"... afterwards, I was taken out and raped every day for 21 days straight. Those were not always the same ... It was random and occasional. My toughest day would be the day after the rape. I would not think about anything. Nothing really mattered... if I live on or If I get killed. Because you know how it is...to loose everything that is yours. Among us, Muslims, no women can get married if she is not a virgin" - dissociation present in this motif.

"They took me by night when they wanted to rape me. Sometimes, three of them would switch on me and sometimes there would be only one. All this time I didn't say anything, because nothing mattered...life or death...".

Fragments from testimony of Croatian woman, 17 years old. Length of captivity: July $18^{\text {th }}-$ December $31^{\text {st }}$ 1993:

"... They imprisoned me in the basement of the elementary school. In a two meters long and one meter wide room, with a tiny window near the top. I slept on a wooden bed, covered with hay and I had one blanket to cover myself. I didn't leave that room for a month... and during this time their commander (identified the person) would send about 5 Muslim soldiers to beat me and rape me, daily. Soldiers would come drugged and drunk...they beat me with their hands and kicked me with their legs everywhere that you could think of. I got hit in the chest a lot. Afterwards, they raped me one by one. I would often lose consciousness...Those soldiers that were sober, after seeing how dirty I was, asked me to do felatio on them ".

Fragments from testimony of Croatian woman, 24 years old, single. Raped multiple times. Held captive in a private house. Length of captivity: End of October (or beginning of November) of 1992 until January $9^{\text {th }} 1993$. This victim became pregnant as a consequence of rape and at her testimony she was in her $3^{\text {rd }}$ month of pregnancy:
"The room in which I was kept was 4 by 4 meters. The room had a closet, king-sized bed and two closets merged together. The room had a single window and you could see the backyard through it, you couldn't see the road. They brought me to this house during the night and on the day of exchange they put a cover over my eyes so I couldn't see from where they were taking me...I couldn't see from which house they were taking me...Likewise, I can't even remember, as you see, what was the exact date when they captured me. I want to forget all of that as soon as possible".

\section{Analysis}

Based on these testimonies, we can highlight the possibility that the extreme traumatic events such as multiple rape, forceful detention and captivity in war might not have been stored in the visual memory of the victims (non-pictorial experience). Contextual representations have been claimed to actively reduce intrusions by anchoring encoded perceptual data for an event in memory (Pearson 2012). The recalling of these traumatic events is devoid of any accompanying perceptual (quasiperceptual conscious experience) and the emotional determinants of the event. All of those victims are unable to make elaborative and affective repetition of something that happened to them. The vividness of this mental imagery is determined by the extent to which people are able to temporarily store and manipulate sensory details in the working memory (Baddeley \& Andrade 2000). In contrast to this, the vividness of the multiple rape events is lacking since it is limited by the quality of the previously stored content by the victim. This content cannot be properly retrieved and described afterwards. Our assumption is that this could be occurring due to a conflict of two or more sensory modalities - the victim is "overloaded" with sensory input that originates from multiple sources in a specific place, during a specific time, as seen in rape events. Welch (1999) proposes that cognitive and non-cognitive factors are in mutual interaction and can result in a "intersensory bias". These sensory inputs can be in conflict with each other and can influence each other to a great extent, resulting in the distortion of temporal and spatial perceptions (Welch 1999). To such a degree, the traumatic event becomes only perceptively marked in the memory, but it remains truncated and devoid of many characteristics - acts in fashion of an episodic buffer (Baddely 2000).

It is important to note that all testimonies presented in this study were first documented interviews that victims had after the rape events took place, before they went to testify in front of the court. Witnesses who experienced rapport before the investigative interview reported a higher percentage of accurate information and a lower percentage of inaccurate information (both misinformation and other false information) in response to openended questions, than those witnesses who experienced no rapport. Thus, building rapport particularly in the 
presence of misinformation improved witness memory (Kieckhaefer at al. 2014).

These observed dynamics that were examined and provided in this study could significantly change palpable prejudices that surround the "the guilt of the abused". To elaborate more on this term - this practically means that the defending lawyers often employ a verbally aggressive approach towards the victim and perpetually pathologize the victim by doing so. This is marked by crudely insisting on sensitive and highly flammable details of the traumatic event that can further retraumatize the victim. Furthermore, these perceptual details often cannot be retrieved and reproduced by the victim who was raped by multiple unknown perpetrators. This lack of perceptual information and the victim's frustration and inability to reproduce the chain of the events in a strict and coherent fashion frequently leads to case dismissal and significantly hinders legal outcomes that would be satisfactory to the victim. Fabricated memories of abuse cannot help the subject to achieve some emotional state that she is seeking to experience, or some understanding of her own current behavior and, if they do not cohere well with the rest of things that the subject remembers about the circumstances surrounding the alleged episode of abuse, and the things that she knows about the participants in that episode (Fernández 2015).

This psychological/psychiatric phenomenon needs to be recognized and evaluated correspondingly during trial, particularly when approaching victims of war rape who were assaulted by previously unknown multiple perpetrators. In cases like this a legal validity can sometimes produce bitter outcomes.

\section{CONCLUSION}

In the testimonies of female victims of multiple sexual assaults, we can ascertain a specific form of expression concerning the traumatic event. This expression entails a significant lack of spatial, temporal and emotional attributes of the event. When discussing the quality of narrative expression, it is important to distinguish between two groups of victims: those who were raped by known vs. those who were raped by the unknown perpetrator(s). This fact has a significant implication on the legal conviction and criminal prosecution of the perpetrator(s) and can drastically alter judicial outcomes. Respectively, a criminal act of rape committed by an unknown perpetrator often interferes with the victim's ability to provide a reliable and credible testimony. Consequently, this results with the lack of evidence that is sine qua non for any further processing of the legal case. An adequate and coherent memory of the victim is significantly complicated by the aberrant perception of the traumatic event due to reasons that could be warrants further investigation Such reasons might include the aberrant memory storage of information, on the level of perceptual sensory input, or memory distortions that could possibly emerge at the level of episodic memory.
Acknowledgements: None.

Conflict of interest: None to declare.

\section{Contribution of individual authors:}

Mirela Vlastelica \& Mladen Lončar drafted the initial manuscript, and reviewed the manuscript.

Josip Anđelo Borovac, Tonći Mastelić \& Domagoj Marković designed the database, collected data, carried out initial analyses, and revised the manuscript.

Slavica Kozina conceptualized and designed the study, coordinated and supervised data collection, and reviewed the manuscript for important intellectual content.

\section{References}

1. Agger I \& Jensen SB: Testimony as ritual and evidence in psychotherapy for political refugees. Journal of Traumatic Stress 1990; 3115-130

2. Aydelott D: Mass rape during war: prosecuting Bosnian rapists under international law. Emory Int'l L Rev 1993; 7:585-92

3. Baddeley $A D$ : Selective attention and performance in dangerous environments. British Journal of Psychology 1972; 63:537-546

4. Baddeley A: The episodic buffer: a new component of working memory? Trends Cogn Sci 2000; 4:417-23

5. Baddeley $A D \&$ Andrade J: Working memory and the vividness of imagery. J Exp Psychol 2000; 129:126-45

6. Bisby JA, Horner AJ, Bush D \& Burgess N: Negative emotional content disrupts the coherence of episodic memories. Journal of Experimental Psychology: General 2018; 147:243-256

7. Bruck $M$ \& Ceci SJ: The suggestibility of children's memory. Annu Rev Psychol 1999; 50:419-39

8. Chaplin JP: Dictionary of Psychology. St. Louis, Tutlerback Books, 1985

9. Cienfuegos AJ \& Monelli C: The testimony of political repression as a therapeutic instrument. Am $J$ Orthopsychiatry 1983; 53:43-51

10. Fergusson DM, Horwood LJ \& Woodward LJ: The stability of child abuse reports: a longitudinal study of the reporting behaviour of young adults. Psychol Med 2000; 30:529-44

11. Fernández $J:$ What are the benefits of memory distortion? Consciousness and Cognition 2015; 33:536-547

12. Freyd JJ: Betrayal trauma: The logic of forgetting childhood abuse. Cambridge, MA, Harvard University Press, 1996

13. Freyd JJ, Klest $B$ \& Allard CB: Betrayal trauma: relationship to physical health, psychological distress, and a written disclosure intervention. $J$ Trauma Dissociation 2005; 6:83-104

14. Geiselman $E \&$ Fisher RP. Interviewing Witnesses and Victims. In: Michel St. Yves (Ed.), Investigative Interviewing: Handbook of Best Practices. Thomson Reuters Publishers, Toronto, 2014 
15. Hyman IE \& Loftus EF: Errors in autobiographical memory. Clinical Psychology Rev 1998; 18:933-947

16. Kieckhaefer JM, Vallano JP \& Schreiber Compo N: Examining the positive effects of rapport building: when and why does rapport building benefit adult eyewitness memory? Memory 2014; 22:1010-23

17. Kijak $M$ \& Pelento ML: Mourning in certain situation of social catastrophe. International Review of Psycho Analysis 1986; 13:436-471

18. Lamb ME, Sternberg KJ, Orbach Y, Esplin PW, Phoenix, Stewart H \& Mitchell S: Age Differences in Young Children's Responses to Open-Ended Invitations in the Course of Forensic Interviews. Journal of Consulting and Clinical Psychology In the public domain 2003; 71:926-934

19. Lončar M, Medved V, Jovanović N \& Hotujac L. Psychological consequences of rape on women in 1991-1995 war in Croatia and Bosnia and Herzegowina. Croat Med J 2006; 47:67-75

20. Mandler G: Recognizing: The judgment of previous occurrence. Psychological Rev 1980; 87:252-271

21. Mlinarević G, Čaušević J \& Čaušević J: Procesuiranje ratnog seksualiziranog nasilja na Sudu Bosne i Hercegovine: šta se dogodilo sa interesom pravde? Analiza i preporuke $u$ vezi sa rodno osjetljivim praćenjem suđenja za ratno seksualizirano nasilje u Bosni i Hercegovini u periodu 23. maj 2011. - 25. maj 2012. Sarajevo, ACIPS, 2012

22. Moran TP: Anxiety and working memory capacity: A meta-analysis and narrative review. Psychol Bull 2016; 142:831-64

23. Morgan CA, Hazlett G, Doran A, Garrett S, Hoyt G, Thomas P, Baranoski $M$ \& Southwick SM: Accuracy of eyewitness memory for persons encountered during exposure to highly intense stress. Int $J$ Law Psychiatry 2004; 27:265-79

24. Office of the Prosecutor International Criminal Tribunal for the former Yugoslavia. Prosecuting sexual Violence Legacy Project, 2015

25. OSCE Mission to Bosnia and Herzegovina. Combating Impunity for Conflict-Related Sexual Violence in Bosnia and Herzegovina: Progress and Challenges. An analysis of criminal proceedings before the Court of Bosnia and Herzegovina between 2005 and 2013. Sarajevo, 2014

26. Pearson D, Ross $F \&$ Webster V: The importance of context: evidence that contextual representations increase intrusive memories. Journal of Behavior Therapy and Experimental Psychiatry 2012; 43:573-580

27. Porter S, Woodworth M, Earle J, Drugge J \& Boer D: Characteristics of sexual homicides committed by psychopathic and nonpsychopathic offenders. Law and human behavior 2003; 27:459-470
28. Pylyshyn ZW: Vision and cognition: how do they connect? Response. Behavioral and Brain Sci 1999; 22:401-423

29. Pylyshyn ZW: Mental Imagery: In search of a theory. Available at: http://cmap.upb.edu.co/rid=1146063079343 661746263_9459/Mental\%20Imagery\%20In\%20search\% 20of\%20a\%20theory_Zenon\%20W.\%20Pylyshyn.pdf

30. Somers MR: The narrative constitution of identity: $A$ relational and network approach. Theory and Society 1994; 23:605-649

31. Tulving E: Episodic memory and autonoesis: Uniquely human? In: Terrace HS, \& Metcalfe J (Eds.), The Missing Link in Cognition (pp. 4-56). NewYork, NY, Oxford University Press, 2005

32. Tulving E: Remembering and knowing the past. American Scientist. 1989;77:361-367

33. Tulving E: Elements of episodic memory. New York, Oxford University Press, 1983

34. Tulving E: Memory and consciousness. Canadian Psychology 1985; 26:1-12

35. Tulving E: Human memory. In: Anderson P, Hvalby $O$, Paulson $O \&$ Hokfelt B (Eds.), Memory concepts - 1993: Basic and clinical aspects (pp. 27-45). Amsterdam, Elsevier Science, 1993

36. Tulving E: What is episodic memory? Current Directions in Psychological Science 1993; 2:67-70

37. Tulving $E$ \& Markowitsch HJ: Episodic and declarative memory: role of the hippocampus. Hippocampus 1998; 8:198-204

38. Tulving E: Episodic memory: from mind to brain. Ann Rev Psychol. 2002; 53:1-25

39. United Nations High Commissioner for Refuges (UNHCR): Sexual and Gender-Based Violence against Refuges, Returness and Internally Displaced Persons. Guidelines for Prevention and Response, 2003:7

40. Vallano JP \& Schreiber Compo N: A Comfortable Witness Is a Good Witness: Rapport-Building and Susceptibility to Misinformation in an Investigative Mock-Crime Interview. Appl Cognit Psychol, 2011 doi: 10.1002/acp.1789

41. van der Kolk BA, Hopper JW \& Osterman JE: Exploring the Nature of Traumatic Memory: Combining Clinical Knowledge with Laboratory Methods. In: Trauma and Cognitive Science: A Meeting of Minds, Science, and Human Experience (Ed: Freyd JJ, \& De Prince AP). The Haworth Maltreatment and Trauma Press, 2001; 9-31

42. Weber RP: Basic content Analysis. SAGA Publications, 1990

43. Welch RB: Meaning, attention, and the "unity assumption" in the intersensory bias of spatial and temporal perceptions. Advances in Psychology 1999; 129:371-387

Correspondence:

Professor Mirela Vlastelica, MD, PhD

School of Medicine, University of Split

21000 Split, Croatia

E-mail: mirela.vlastelica@icloud.com 